\title{
Removal of Dyes from Aqueous Solution Using Activated Carbon Embedded Cryogels
}

\section{Aktif Karbon Gömülü Kriyojeller ile Sulu Çözeltiden Boya Giderimi}

\section{Ceren Haktanır ${ }^{\circ}$}

Department of Advanced Technologies, Gazi University, Ankara, Turkey.

\section{A B STR ACT}

$\mathrm{n}$ this study poly(hydroxyethyl methacrylate) (PHEMA) based activated carbon (AC) embedded cryogel discs were synthesized, characterized and their application for dye removal from aqueous solutions were investigated. The effect of $\mathrm{pH}$ and initial dye concentration on the adsorption capacity of the cryogels were studied in a batch system. Desorption of dyes was also studied and it was shown that synthesized composite system could be repeatedly used without significant loss in the adsorption capacity after five repetitive adsorption-desorption processes.

\section{Key Words}

Adsorption, dye, activated carbon, cryogel.

u çalışmada poli (hidroksietil metakrilat) (PHEMA) esaslı aktif karbon (AC) gömülü kriyojel diskleri sentezlenip, karakterize edilmiş ve sulu çözeltilerden boya giderimi performnsı araştırılmıştır. pH ve başlangıç boya derişimlerinin kriyojenlerin adsorpsiyon kapasiteleri üzerindeki etkisi kesikli sistemde incelenmiştir. Boyaların desorpsiyon çalışmaları gerçekleştirilmiş ve ard arda yapılan beş adsorpsiyon-desorpsiyon işleminden sonra sentezlenen kompozit sistemin adsorpsiyon kapasitesinde önemli bir kayıp olmadan tekrar tekrar kullanılabileceği gösterilmiştir.

\section{Anahtar Kelimeler}

Adsorpsiyon, boya, aktif Karbon, kriyojel. 


\section{INTRODUCTION}

- nvironmental contamination due to wastewater - discharges containing high concentrations of dyes is an important environmental issue since the effluents discharged from dyeing industries are highly colored and also contain large amounts of organic solid [1]. Most of these dyes are harmful for aquatic life or to humans by mutagenic and carcinogenic effect when in contact for a long time [2]. Dyes generated from textile industries are difficult to biodegrade due to their structural stability [3].

Various conventional wastewater threatment methods are present, such as coagulation and flocculation [4], ozonation [5], electrochemical techniques [6], fungal decolorization [7] and adsorption [8]. In recent years, adsorption has increasingly received much attention since the method is simple, relatively low-cost and effective for polutants inwater [1].

There are several research articles focusing on the development and characterization of new adsorbents such as polymeric materials, biomass, monoliths, cryogels, molecularly imprinted polymers etc. [12-21]. Cryogels having many advantages, like structural flexibility, large pores and short diffusion pathways, can be one of the best choices for adsorption of dye molecules. They are also cheap, simple to produce in any shape and are not toxic to the environment [19]. However, they have relatively low specific surface area resulting in low adsorption capacity in the adsorption process. In order to overcome this drawback, composite cryogels can be synthesized by embedding appropriate particles for the desired separation or purification $[22,23]$.

Activated carbons are excellent and versatile adsorbents. Their important applications are the adsorptive removal of color, odor, and taste, and other undesirable organic and inorganic pollutants from drinking water, treatment of industrial waste water; air purification in inhabited spaces, such as in restaurants, food processing, for the purification of many chemical, food, and pharmaceutical products; and in a variety of gas-phase applications [24]. Research has been carried out in the area of activated carbon adsorption during the past four or five decades. In recent literature, activated carbons from different origins have been used for dye removal [25-30].
In this study, high adsorption capacity of activated carbon and unique properties of cryogels are combined and activated carbon embedded, composite PHEMA cryogel discs are sythesized for the removal of selected dyes. The composite system is characterized using swelling tests and SEM. Dye adsorption capacities of the composite cryogel discs at various $\mathrm{pH}$ and initial metal concentrations are studied. The reusability of the synthesized cryogels are tested for five repeated runs.

\section{MATERIALS and METHODS \\ Materials}

2-hydroxyethyl methacrylate (HEMA) were obtained from Fluka A.G. (Buchs, Switzerland). Ammonium persulfate (APS), N,N'-methylene-bis(acrylamide) (MBAAm), N,N,N',N'-tetramethylene diamine (TEMED) and the dyes used in the experiments were purchased from Sigma-Aldrich (Germany). Activated carbon in powder form was obtained from Merck AG (Darmstadt, Germany). All other chemicals used were reagent grade and were purchased from Merck AG (Darmstadt, Germany). Water used in the adsorption experiments was purified using a Barnstead (Dubuque, IA, USA) ROpure LPÒ reverse osmosis unit with a high flow cellulose acetate membrane (Barnstead D2731) followed by a Barnstead D3804 NANOpureÒ organic/colloid removal and ion exchange packed-bed system. The resulting purified water has a specific conductivity of $18 \mathrm{M} \Omega / \mathrm{cm}$. All glassware was washed with diute nitric acid solution and rinsed with deionized water before use.

\section{Preparation of PHEMA-AC Cryogel Discs}

Monomers (1.6 mL HEMA and $0.3 \mathrm{~g} \mathrm{~N}, \mathrm{~N}$-methylenebis(acrylamide) (MBAAm) were dissolved in deionized water $(5 \mathrm{~mL})$ and the mixture was $d$ egassed under vacuum for about $5 \mathrm{~min}$ to eliminate soluble oxygen. Total concentration of monomers was $16 \%$ (w/v). $3.0 \mathrm{mg}$ activated carbon (AC) was added to the resulting solution and stirred until a homogeneous suspension is achieved. The cryogel was produced by free radical polymerization initiated by TEMED and APS. After adding APS (20 $\mathrm{mg}, 1 \%(\mathrm{w} / \mathrm{v})$ of the total monomers) the solution was cooled in an ice bath for 2-3 min. Then, TEMED $(20 \mu \mathrm{L}$, $1 \%(\mathrm{w} / \mathrm{v})$ of the total monomers) was added and the reaction mixture was stirred for $1 \mathrm{~min}$. Then, the reaction mixture was poured between two glass plates separated with $1.5 \mathrm{~mm}$ thick spacers. The polymerization solution in the plates was frozen at $-16{ }^{\circ} \mathrm{C}$ for $24 \mathrm{~h}$ and then thawed at room temperature. The resulting cryogel sheets were cut into circular pieces ( $2 \mathrm{~cm}$ diameter) 
with a perforator. The cryogels were extensively washed with ethanol and water to remove any unreacted monomer or initiator and then stored in sodium azide $0.02 \%$ at $4{ }^{\circ} \mathrm{C}$

\section{Characterization of PHEMA-AC cryogels}

Swelling ratios of composite cryogel discs were determined in distilled water. Cryogel disc sample was washed on porous filter paper until washing solution is clear. Then, it was dried to constant mass weight in the oven at $600 \mathrm{C}$ and was weighed carefully $( \pm 0.0001 \mathrm{~g})$ before placing in a $50 \mathrm{~mL}$ vial containing distilled water (WO). The vial was put into an isothermal water bath with a fixed temperature $\left(25.0 \pm 0.5^{\circ} \mathrm{C}\right)$ for $2 \mathrm{~h}$. The cryogel was taken out of the medium, wiped using a filter paper, and weighed (WS). The swelling ratio was calculated by using Equation 1.

$$
\text { Swelling Ratio } \%=\frac{\mathrm{w}_{\mathrm{S}}-\mathrm{W}_{0}}{\mathrm{w}_{0}} \times 100 \%
$$

Where, WO and WS are the weights (g) of cryogels before and after swelling, respectively.

\section{The surface morphology of the com} posite cryogel discs were examined using scanning electron microscopy (SEM, JSM-6400, JEOL) at an accelerating voltage of $20 \mathrm{kV}$ after coating the samples with gold. The samples were initially dried in air at $25^{\circ} \mathrm{C}$ for 7 days before being analyzed. The surface of the sample was then scanned at the desired magnification to study the morphology of the cryogels.

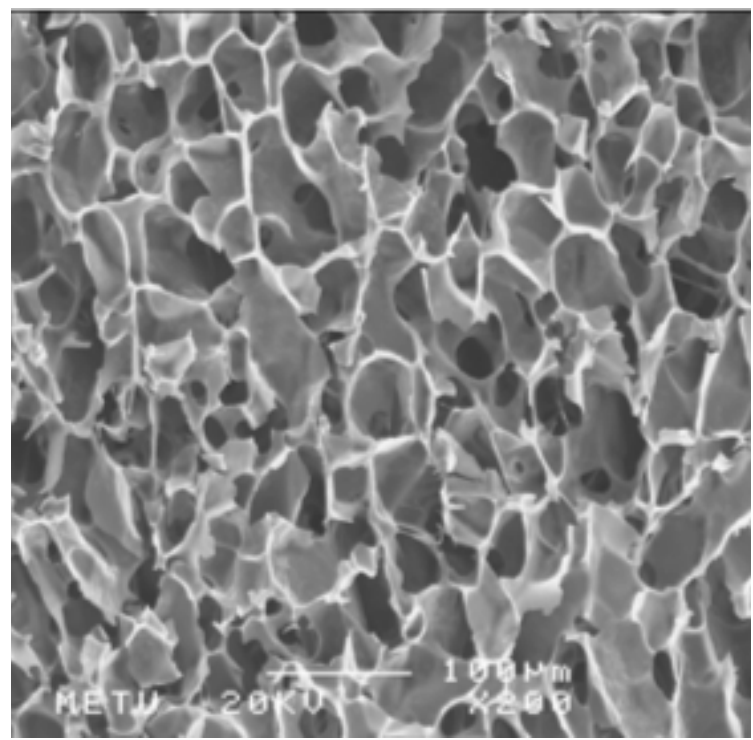

\section{Dye Adsorption Studies from Aqueous Solutions}

Adsorption of all three dyes on the composite cryogels from aqueous solutions was studied in batch systems. The effects of $\mathrm{pH}$ and initial dye concentration on adsorption were investigated in a $25 \mathrm{ml}$ buffer solution. The adsorption studies were conducted at different $\mathrm{pH}$ values between 4-9 and different initial dye concentrations between 50-300 mg/L. In the adsorption experiments, 0.09 g cryogel discs were added to the corresponding buffer solutions. The flasks were shaken in a 25 ${ }^{\circ} \mathrm{C}$ water bath at a speed of $150 \mathrm{rpm}$. After the desired adsorption period (up to $180 \mathrm{~min}$ ), dye concentration in the aqueous phase was measured using a Schimadzu UV-1601 spectrophotometer. The percent dye adsorptions were calculated by using Equation 2.

\section{\%Adsorption $=\frac{\left(\mathrm{C}_{0}-\mathrm{C}\right)}{\mathrm{C}_{0}} \quad(2)$}

Where $\mathrm{CO}$ and $\mathrm{C}$ are the initial and equilibrium concentrations of dye molecules in the aqueous solution $(\mathrm{mg} / \mathrm{L})$, respectively.

Dye desorption studies were also performed in a batch system using a $20 \mathrm{~mL} \mathrm{NaOH}$ solution having a concentration of $0.5 \mathrm{M}$. Cryogels were placed in the desorption medium and shaken in a water bath shaker at a rate of $150 \mathrm{rpm}$ for $120 \mathrm{~min}$. The concentration of metal ions in desorption medium were obtained as described before. The desorption ratio was calculated from the amount of metal ions adsorbed on the cryogels and the final metal ions concentrations in the desorption medium.

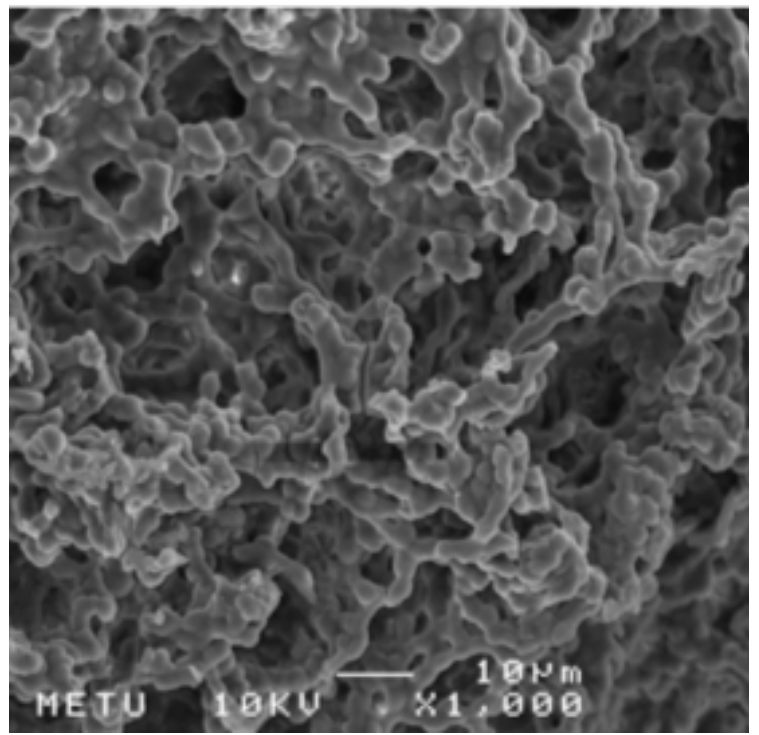

Figure 1. SEM images of plain PHEMA discs (a) and PHEMA-AC composite discs (b). 


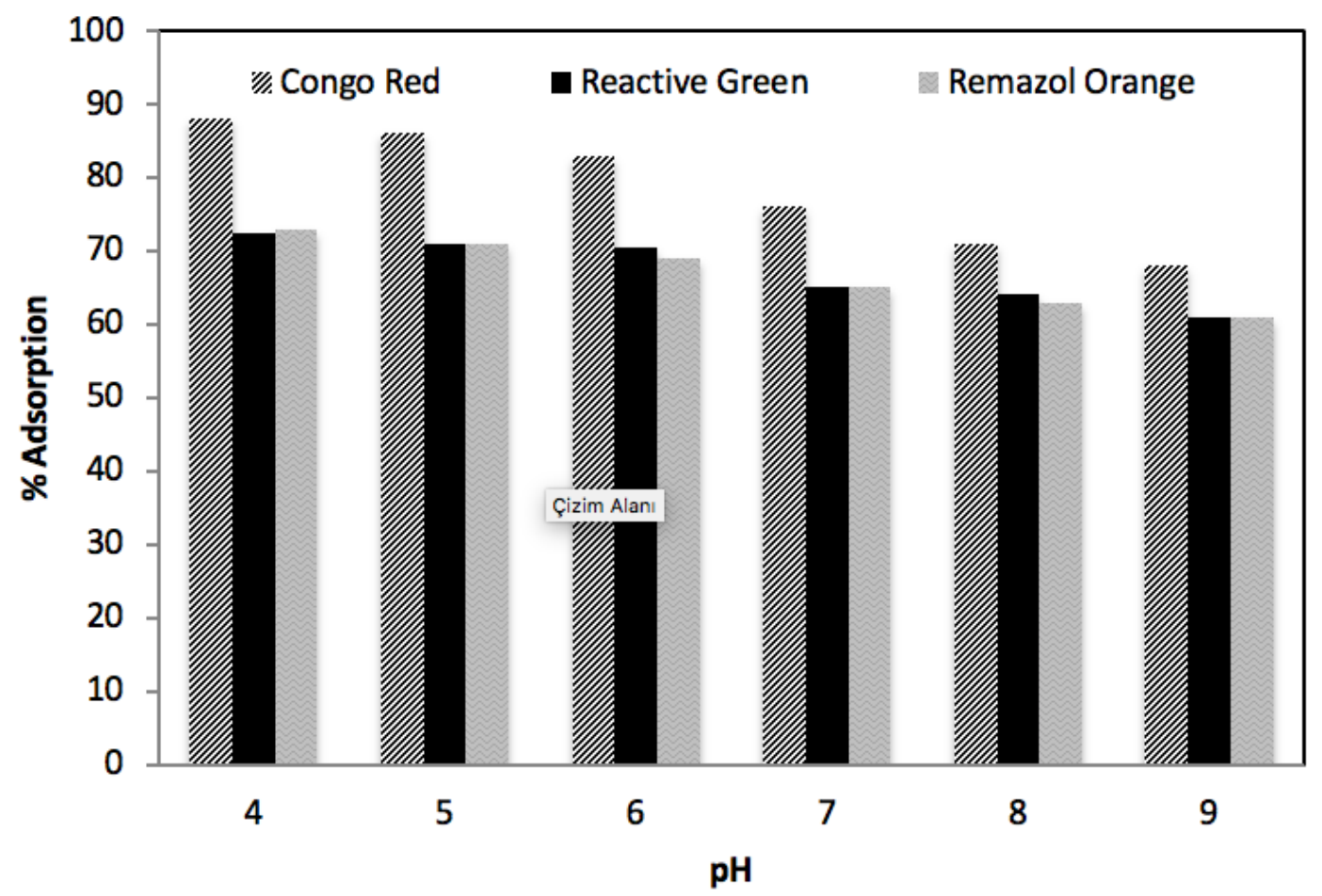

Figure 2. Effect of $\mathrm{pH}$ on dye adsorption using PHEMA-AC composite cryogel. (Temperature $=25^{\circ} \mathrm{C}$, Initial Dye Concentration $=200$ $\mathrm{mg} / \mathrm{L})$.

\section{RESULTS and DISCUSSION Characterization of the Synthesized PHEMA-AC Cryogel Discs}

Cryogel discs were synthesized by radical polymerization in the frozen state using HEMA as monomer with MBAA as a cross linker in the presence of APS/ TEMED as initiator/activator pair. Activated carbon (AC) particles were embedded in the structure of the cryogel. Even after the addition of AC particles, the discs maintained their elastic, sponge-like structure. However, when compared with the plain PHEMA cryogels, they were less elastic. The swelling ratio and equilibrium swelling degree of PHEMA-AC cryogel discs were and $626 \%$ and $6.42 \mathrm{~g} \mathrm{H} 2 \mathrm{O} / \mathrm{g}$ cryogel respectively. The synthesized cryogel discs were also characterized by SEM. The SEM images of the plain PHEMA discs and PHEMA-AC discs were given in figure $1 \mathrm{a}-\mathrm{b}$, respectively.

In the figure it is seen that, both of the cryogels have interconnected continuous pores between 10-100 $\mu \mathrm{m}$. It was observed from figure $1 \mathrm{~b}$ that the activated carbon particles were successfully embedded to the structure of PHEMA cryogel. The interconnected pores and macroporosity of the cryogels provide easy diffusion of dye molecules into the structure and may lead to effective interactions between the dyes and composite cryogel discs.

\section{Dye Adsorption on PHEMA-AC Cryogel Discs}

Adsorption behavior of the dye molecules on cryogel discs was studied at different initial dye concentration and $\mathrm{pH}$ in batch mode to obtain the optimum conditions for dye adsorption.

\section{Effect of pH}

The $\mathrm{pH}$ of the solution is an important parameter to validate the feasibility of the adsorption process. It plays an important role on the adsorption capacity by influencing the chemistry of both dye molecule and activated carbon in aqueous solution [2]. The effect of $\mathrm{pH}$ on the adsorption capacity of the composite cryogels was investigated in the $\mathrm{pH}$ range between 4.0 and 7.0 with an initial dye concentration of $200 \mathrm{mg} / \mathrm{L}$.

In Figure 2 the effect of $\mathrm{pH}$ on dye adsorption using composite cryogel discs is demonstrated. For all of the dye molecules, adsorption is favorable in acidic conditions. This behavior may be explained by the behavior of dye molecules and activated carbon in acidic solutions. The activity of commercial activated carbon is due to the presence of functional groups such as; carbocylic, phenolic, etc. These functional groups possess anionic properties at higher $\mathrm{pH}$ values. All of the dyes studied 


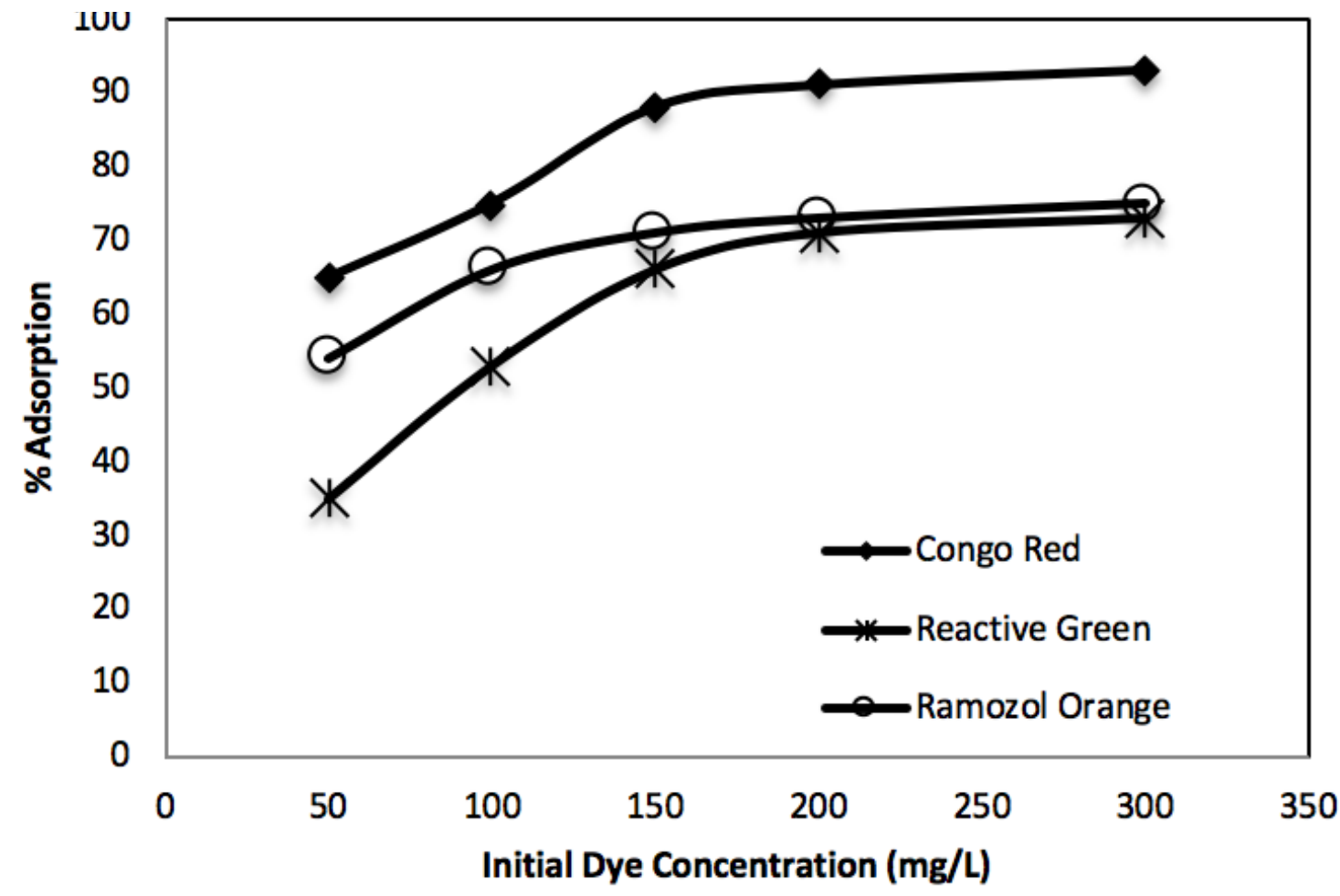

Figure 3. Effect of initial dye concentration PHEMA-AC composite cryogel at $25^{\circ} \mathrm{C}$. $(\mathrm{pH}=4.0)$.

are anionic dyes. Therefore, due to ionic repulsion between the anionic dye and negatively charged surface, the adsorption of molecules on the composite cryogel is low. Besides, the surface of the activated carbon can be excessively protonated at low $\mathrm{pH}$ values, which results in in an increase in dye adsorption.

Figure 3 shows the dye adsorption curves for PHEMAAC cryogels. These adsorption curves were obtained by the adsorption of dye molecules on the synthesized composite system at different initial dye concentrations. The dye concentrations were changed between $50-300 \mathrm{mg} / \mathrm{L}$. The percent adsorption of dye molecules first increased with the initial concentration then reached a plateau value, which represents the saturation of the active sites available for dye adsorption on the PHEMA-AC cryogel. Similar behaviors were obtained for all three dyes. Saturation levels at a bulk concentration of approximately $300 \mathrm{mg} / \mathrm{L}$ were reached for all of the dye solutions. The maximum percent adsorption of Congo Red, Remazol Orange and Reactive Green were obtained as $93 \%, 75 \%$ and $74 \%$, respectively. It was observed that PHEMA-AC cryogel had more affinity towards Congo red.
Reusability of synthesized adsorbent is an important criteria in adsorption processes. PHEMA-AC cryogel loaded with the maximum amounts of the target dye molecules were placed in desorption medium containing $0.5 \mathrm{M} \mathrm{NaOH}$ and the amount of metal ions desorbed in $2 \mathrm{~h}$ was measured. High desorption ratios up to $95 \%$ were obtained for all three dyes. Adsorption-desorption cycle was repeated five times using the same cryogel to investigate the reusability of the composite cryogels (Figure 4). Adsorption capacity of the PHEMA-AC cryogel did not change significantly during the repeated adsorption-desorption cycles, implying that the synthesized cryogel can repeatedly be used in the adsorption process without loosing its adsorption capacity.

\section{Conclusions}

Cryogels can be one of the best choices for adsorption of dye molecules since they have structural flexibility, large pores and short diffusion pathways. Moreover they are cost friendly and can be scaled up for industrial applications. On the other hand, due to relatively low specific surface area they have low adsorption capacity in the adsorption process. In order to overcome this drawback, in this study, activated carbon having high adsorption capacity was embedded in the structure of PHEMA cryogel discs. Plain PHEMA discs had very low 


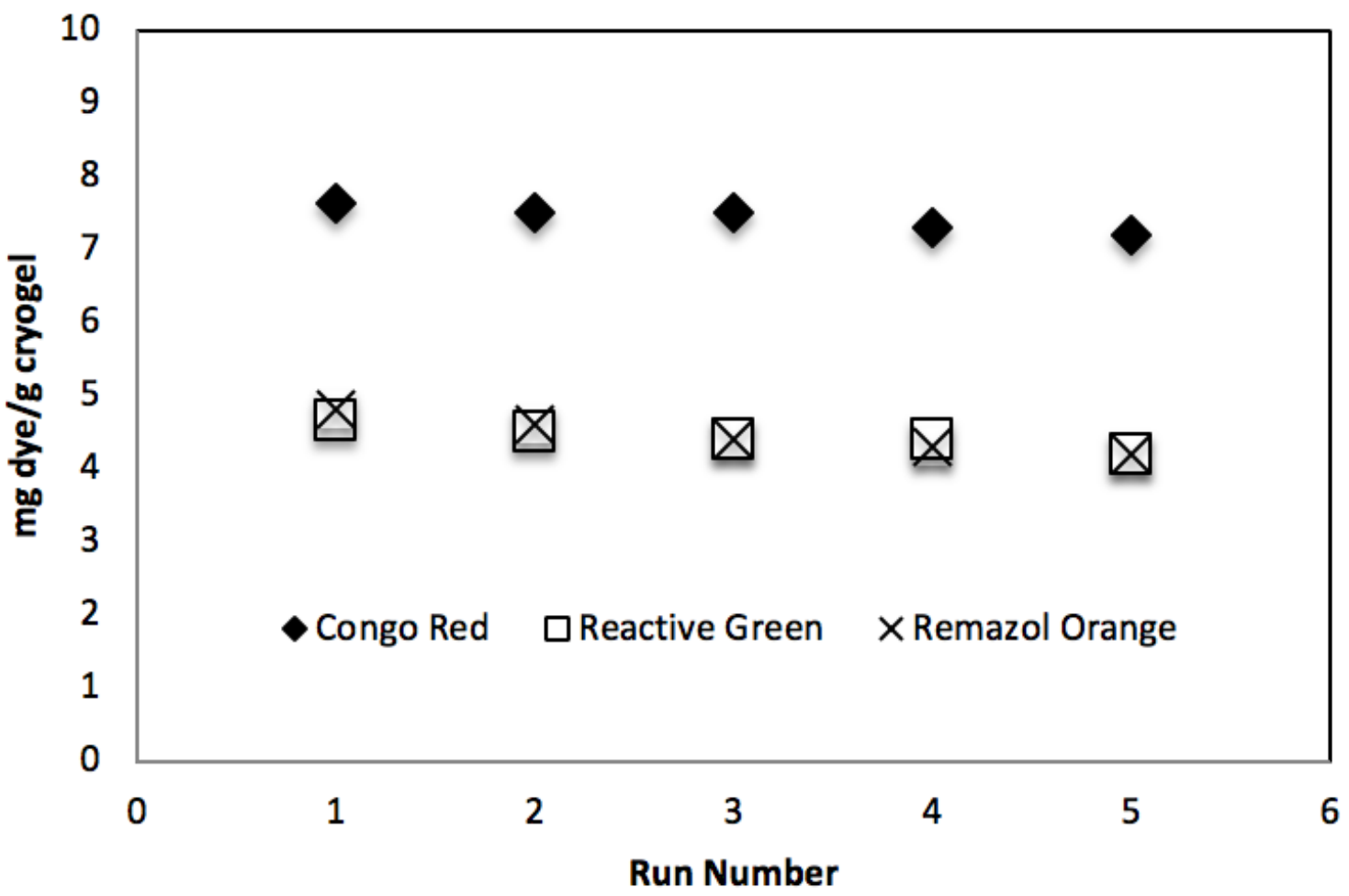

Figure 4. Adsorption-desorption cycle of PHEMA-AC composite cryogels. Metal ion concentration: $100 \mathrm{mg} / \mathrm{L} ; \mathrm{pH}: 7$; temperature: $25^{\circ} \mathrm{C}$.

dye adsorption capacities. The addition of $A C$ in the structure of PHEMA increased the adsorption capacities significantly. It can be concluded that embedding plays an important role for the increase in the adsorption capacity of a cryogelic adsorbent and the material proposed can be utilized as an efficient adsorbent and an alternative for the control of dye pollution in aqueous solutions.

\section{References}

1. T. Santhi, S. Manonmani, T. Smitha, Removal of Methyl Red drom Aqueous Solution by Activated Carbon Prepared from the Annona squmosa seed by Adsorption, 14 (2010) 11-18.

2. M.K. Purkait, A. Maiti, S. DasGupta, S. De, Removal of congo red using activated carbon and its regeneration, J. of Hazardous Mat., 145 (2007) 287-295.

3. C. Namasivayam, D. Kavitha, Removal of congo red from water by adsorption onto activated carbon prepared from coir pith, an agricultural waste, Dyes Pigments, 54 (2002) 47-58.

4. A. Kumar, V. Rajesh, R. Dash, P. Bhunia, A review on chemical coagulation/flocculation technologies for removal of colour from textile wastewaters, J. Env. Manag., 93 (2012) 154-168.

5. W. Chu, C. Ma, Quantitative prediction of direct and indirect dye ozonation kinetics, Wat. Res. 34 (12) (2000) 3153-3160.

6. B.K. Körbahti, K. Artut, C. Geçgel, A. Özer, Electrochemical decolorization of textile dyes and removal of metal ions from textile dye and metal ion binary mixtures, Chem. Eng. J., 173 (2011) 677-688.

7. M.T. Yagub, T.K. Sen, S. Afroze, H.M. Ang, Dye and its removal from aqueous solution by adsorption: A review, Adv. Coll. Interf. Sc., 209 (2014) 172-184

8. N.W. Wang, Y. Chu, F.Wu, Z.Zhao, X. Xu, Decolorization and degradation of Congo red by a newly isolated white rot fungus, Ceriporia lacerata, from decayed mulberry branches, Intern. Biodeter. Biodegr., 117 (2017) 236-244.

9. F. Augusto, E. Carasek, R.G. Silva, S.R. Rivellino, A.D. Batista, E. Martendal, New sorbents for extraction and microextraction techniques, J. Chromatogr. A, 1217 (2010) 2533-2542.

10. B.L. Rivas, M. Jara, E.D. Pereira, Preparation and adsorption properties of the chelating resins containing carboxylic, sulfonic, and imidazole groups, J. Appl. Polym. Sci., 89 (10) (2003) 2852-2856

11. B.L. Rivas, E. Pereira, M. Jara, C. Esparza, Resins with the ability to bind copper and uranyl ions, J. Appl. Polym. Sci., 99 (2006) 706-711.

12. E. Dana, A. Sayari, Preparation and characterization of PEG bis(amine) grafted PMMA/SPION composite nanoparticles, Desal., 285 (2012) 62-71.

13. S. Senel, L. Uzun, A. Kara, A. Denizli, Heavy Metal Removal from synthetic solutions with magnetic beads under magnetic field, Sci. Pure Appl. Chem., 45 (2008) 635-642.

14. D.W. O'Connell, C. Birkinshaw, T.F. O'Dwyer, A modified Cellulose Adsorbent for the removal of $\mathrm{Ni}(\mathrm{II})$ from aqueous solutions, J. Chem. Technol. Biotechnol., 81(11) (2006) 1820

15. D.W. O'Connell, C. Birkinshaw, T.F. O'Dwyer, A chelating cellulose adsorbent for the removal of $\mathrm{Cu}(\mathrm{II})$ from aqueous solutions, J. Appl. Polym. Sci., 99 (2005) 2888-2897. 
16. W.L. Ningmei, L. Zhengkui, Synthesis and characterization of poly(HEMA/MALA) hydrogel and its application in removal of heavy metal ions from water, Chem. Eng. J., 894 (2013) 215-216.

17. L. Onnby, C. Giorgi, F.M. Plieva, B. Mattiasson, Removal of heavy metals from water effluents using supermacroporous metal chelating cryogels, Biotechnol. Prog., 26 (2010) 12951302.

18. O. Ozay, S. Ekici, Y. Barana, S. Kubilay, N. Aktas, N. Sahiner, Utilization of magnetic hydrogels in the separation of toxic metal ions from aqueous environments, Desalination, 260 (2010) 57.

19. E. M. Dursun, R. Üzek, N. Bereli, S. Şenel, A. Denizli, Synthesis of novel monolithic cartridges with specific recognition sites for extraction of melamine, React. Funct. Polym., 109 (2016) 33-41.

20. E. Tamahkar, M. Bakhshpour, M. Andaç, A. Denizli, Ion imprinted cryogels for selective removal of $\mathrm{Ni}(\mathrm{II})$ ions from aqueous solutions, Separ. Purif. Technol., 179 (2017) 36-44.

21. L. Uzun, H. Yavuz, R. Say, A. Ersöz, A. Denizli, Poly(ethylene dimethacrylate-glycidyl methacrylate) monolith as a stationary phase in dye-affinity chromatography, Ind. Eng. Chem. Res., 43 (2004) 6507-6513.

22. H. Kirsebom, B. Mattiasson, I.Y. Galaev, Building macroporous materials from microgels and microbes via one-step cryogelation, Langmuir, 25 (2009) 8462.

23. H. Kirsebom, D. Topgaard, I.Y. Galaev, B. Mattiasson, Modulating the porosity of cryogels by influencing the nonfrozen liquid phase through the addition of inert solutes, Langmuir, 26 (2010) 16129.

24. R.C. Mansal, M.Goyal, Activated Carbon Adsorption, Taylor \& Francis Group, LLC, CRC Press, Boca Raton, 2005.

25. S. Rattanapan, Jiraporn Srikram, P. Kongsune, Adsorption of methyl orange on coffee grounds activated carbon, Energy Procedia, 138 (2017) 949-954.
26. K.W. Jung, B.H. Choi, M. J. Hwang, J.W. Choi, S.H. Lee, J.S. Chang, K.H. Ahn, Adsorptive removal of anionic azo dye from aqueous solution usingactivated carbon derived from extracted coffee residues, J. Cleaner Prod., 166 (2017) 360368.

27. M. Daouda, O. Benturkia, Z. Keciraa, P. Girodsc, A. Donnot, Removal of reactive dye (BEZAKTIV Red S-MAX) from aqueous solutionby adsorption onto activated carbons prepared from date palm rachisand jujube stones, J. Molec. Liq., 243 (2017) Pages 799-809

28. M. Baysal, K. Bilge, B. Yılmaz, M. Papila, Y.Yürüm, Preparation of high surface area activated carbon from waste-biomass ofsunflower piths: Kinetics and equilibrium studies on the dye removal, J. Environ.I Chem. Eng., 6 (2018) 1702-1713

29. H. Trevino-Cordero, L.G. Juárez-Aguilar, D.I. MendozaCastillo, V. Hernández-Montoya, Synthesis and adsorption properties of activated carbons from biomass of Prunus domestica and Jacaranda mimosifolia for the removal of heavy metals and dyes from water, Ind. Crops Pro., 42 (2013) 315-323.

30. S. Belloa, K.A. Adegokec, O. Oluwapamilerin Sarumia, O. Seun Lameed, Functionalized locust bean pod (Parkia biglobosa) activated carbon forRhodamine B dye removal, Heliyon, 5 (2019) e02323.

31. D. Garg, C.B. Majumder, S.Kumara, B. Sarkar, Removal of Direct Blue-86 dye from aqueous solution using alginateen capsulated activated carbon (PnsAC-alginate) prepared from waste peanutshell, J. Env. Chem. Eng., 7 (2019) 103365.

32. N.Boudechiche, M. Fares, S. Ouyahia, H. Yazid, M. Trari, Z. Sadaoui, Comparative study on removal of two basic dyes in aqueous medium by adsorption using activated carbon from Ziziphus lotus stones, Microchem. J., 146 (2019) 10101018

33. M. Alkan, M. Dogan, Y. Turhan, O. Demirbas, P. Turan, Adsorption kinetics and mechanism of maxilon blue $5 \mathrm{G}$ dye on sepiolite from aqueous solutions, Chem. Eng. J., 139 (2008) 213. 